\title{
VANILLIC ACID INHIBITS LUNG CARCINOGENESIS BY MODULATES GLYCOPROTEIN ABNORMALITIES, MEMBRANE-BOUND ENZYMES, AND INFLAMMATORY MARKERS
}

\author{
SATHESH KANNA VELLI ${ }^{1}$, DEVAKI THIRUVENGADAM ${ }^{{ }^{*}}$
}

1Department of Biochemistry, University of Madras, Guindy Campus, Chennai-600025, India

Email: devakit@yahoo.co.uk

Received: 11 Dec 2019, Revised and Accepted: 04 Feb 2020

\section{ABSTRACT}

Objective: The current plan was accompanied to explicate the possible protective role of vanillic acid (VA), on modification in lipid peroxidation, inflammatory cytokines, membrane-bound enzymes, and glycoconjugates during B(a)P induced lung cancer in Swiss albino mice.

Methods: Benzo(a)pyrene was administered orally (50 mg/kg b. wt) to induce lung cancer in Swiss albino mice. lipid peroxidation, serum marker enzymes, inflammatory cytokines, membrane-bound ATPases and protein-bound carbohydrate components (Hexose, hexosamine, sialic acid and fucose) and Mast cells and PAS staining were carried out.

Results: Lung cancer possessing animals exhibited increased levels of lipid peroxidation, ADA, AHH, $\gamma$-GT, 5'-NT, LDH, cytokines such as TNF- $\alpha$ and IL-1 $\beta$, protein-bound carbohydrate components (protein-hexose, hexosamine, sialic acid, and fucose) also diminished activity of membrane-bound ATPases $\left(\mathrm{Na}^{+} / \mathrm{K}^{+}\right.$ATPases, $\mathrm{Ca}^{2+}$ ATPases, and $\left.\mathrm{Mg}^{2+} \mathrm{ATPase}\right)$. Treatment with VA significantly ameliorated all these activities

Conclusion: Overall, the present study evidence to the VA has effective anti-inflammatory in addition to free radical scavenging activity for the duration of lung carcinogenesis in Swiss albino mice.

Keywords: Lung cancer, Vanillic acid, Cytokines, Glycoconjugates, Benzo(a)pyrene

(C) 2020 The Authors. Published by Innovare Academic Sciences Pvt Ltd. This is an open-access article under the CC BY license (http://creativecommons.org/licenses/by/4.0/) DOI: http://dx.doi.org/10.22159/ijpps.2020v12i3.36607. Journal homepage: https://innovareacademics.in/journals/index.php/ijpps

\section{INTRODUCTION}

Lung malignancy is one of the most generally diagnosed cancers worldwide, it also ranks first as a foremost cause of cancer-related deaths both men and women [1]. Around $90 \%$ of all lung cancer is instigated through cigarette smoking [2, 3]. Oxidative stressmediated lipid peroxidation (LPO) acting a substantial part of carcinogenesis and most studied relevant to the free radical chain reaction. Glycoproteins are the main constituents of the cell membrane which act as a significant part of cell differentiation, cell proliferation, and cell-cell interaction $[4,5]$. Chemoprevention deals with a unique approach to regulate the incidence and mortality of lung malignancy [6]. In modern years, significant consideration was given to increase in dietetic consumption of phytochemicals because epidemiological, as well as experimental studies, gave an optimistic association between reduced risks of cancer due to intake of phytochemicals [7].

Vanillic acid (VA) is dietetic phenolic derivative natural substances found in vanilla bean and benzoin [8]. It is also found in wine and vinegar [9)]. VA eliminates the ROS as well as hydroxyl radicals and lipid peroxide radicals and also protects the biological membrane by inhibiting lipid peroxidation $[10,11]$ It possesses antioxidant activity [10)], anti-genotoxic [12]. VA has been connected with abundant pharmacological possessions to treat carcinogenesis $[13,14]$, apoptosis [15], and hepatoprotective effects [16]. VA also exhibits a chemopreventive effect in experimentally induced carcinogenesis in rats $[17,18]$. Recently, we have stated the antioxidant and anticancer potential of VA during experimentally induced lung cancer [19].

The current plan was designed to focus the defensive effect of VA on the expression of inflammatory cytokines together with the lipid peroxidation, membrane-bound enzymes, and cell surface abnormalities by assessing the glycoconjugates levels during $\mathrm{B}(\mathrm{a}) \mathrm{P}$ induced lung cancer in albino mice.

\section{MATERIALS AND METHODS}

\section{Chemicals}

Benzo(a)pyrene, vanillic acid, BSA were bought from Sigma chemicals, St Louis, USA. The primary and secondary antibodies obtained from Santa Cruz Biotech, USA. The other chemicals were procured of analytical grade from SRL Chemicals Pvt, Ltd, Mumbai, India. TNF- $\alpha$, IL-1 $\beta$ enzyme-linked immunosorbent assay (ELISA) kits were obtained from Thermo Fisher Scientific.

\section{Experimental proposal}

All the experiments were considered and carried out according to the Institutional Animal Ethical Committee agreed guidelines (IAEC No.01/05/2018). Healthy male mice obtained from the veterinary college (Tanuvas), Chennai. The animals maintained in perfect, sanitized confines at $\left(25 \pm 2{ }^{\circ} \mathrm{C}\right)$ then were adjusted to the 12 -h bright and dusky cycles. Animals were fed with commercially available rat pellet feed (Hindustan Foods Ltd, Bangalore, India).

Mice were randomly dispersed into four groups; each group contains 6 animals, groups classified as follows:

Group I served as control animals and was given corn oil orally for $16 \mathrm{w}$ along with diet and drinking water. Group 2 animals were administered with $\mathrm{B}(\mathrm{a}) \mathrm{P}$ ( $50 \mathrm{mg} / \mathrm{kg}$ b. wt) disbanded in corn oil orally twice a week for 4 subsequent weeks and remain for $16 \mathrm{w}$. Group 3 animals were treated with of VA ( $200 \mathrm{mg} / \mathrm{kg} \mathrm{b}$. wt.) alternate days a week orally for 16 $\mathrm{w}$ along with $\mathrm{B}(\mathrm{a}) \mathrm{P}$. VA treatment was started one week earlier than to the beginning dosage of $\mathrm{B}(\mathrm{a}) \mathrm{P}$ administration and continued until the end of the experimental period. Group 4 animals were treated with of VA (200 mg/kg b. wt.) alternating days a week orally for $16 \mathrm{w}$. At the end of the experimental period, the animals were fasted throughout the night, anesthetized followed by cervical decapitation. The serum and supernatants were collected for evaluating different parameters. The protein was assessed in serum and tissue homogenate by the method [20]. Serum marker enzymes Adenosine deaminase (ADA) [21], AHH [22], $\gamma$-Glutamyl transpeptidase ( $\gamma$-GT) [23], 5'-nucleotidase (5'-NT) [24], and lactate dehydrogenase (LDH) [25] were assayed. Erythrocyte membranes were isolated according to the standard protocol by the method [26] and LPO was evaluated according to [27].

Determination of membrane-bound enzymes and Glycoprotein's

The activity of $\mathrm{Na}^{+} / \mathrm{K}^{+}$ATPase by [28] $\mathrm{Ca}^{2+}$ ATPase by [29] as well as $\mathrm{Mg}^{2+} \mathrm{ATPase}$ by [30] was estimated. Hexose, hexosamine, and fucose determination by [31]. Sialic acid was determined by the method [32]. 


\section{Inflammatory cytokines ELISA}

Serum TNF- $\alpha$ and IL-1 $\beta$ levels were measured by ELISA kits according to the manufacturer's protocol.

\section{Mast cell and PAS staining}

Mast cell staining investigation was performed by the standard procedure [33]. PAS staining investigation was performed by the standard procedure [34]

\section{Western blot analysis of inflammatory cytokines}

Western blot investigation of inflammatory cytokines (TNF- $\alpha$, IL-1 $\beta$ ) was performed by the standard procedure [35]. Densitometry data are denoted in bar graphs as 'fold change' equalled to control.

\section{Statistical analysis}

The data were analyzed by using SPSS/10 software. Data were assessed by one-way analysis of variance (ANOVA) followed by least significance difference (LSD) test. $\mathrm{P}<0.05$ were considered to indicate statistical significance. The entire outcomes were expressed as a mean \pm standard error (SE) for six animals in all groups.

\section{RESULTS}

VA inhibits lipid peroxidation (LPO) in the lung and erythrocyte membrane of control and experimental animals

Fig. 1a shows the B(a)P induced group II animals, there was a considerable increase in the levels of lung and erythrocyte membrane lipid peroxides while compared with group I animals. Whereas VA treated group III animals, there is a substantial reduction in the altitudes of lipid peroxides while compared to group II animals. However, there were no noticeable changes observed in group IV animals while compared to group I animals.

VA decreased the levels of serum marker enzymes in experimental conditions

Fig. 2 represents the effect of VA on the levels of serum marker enzymes in control and experimental animals. Serum marker enzymes ADA, AHH, $\gamma$-GT, 5'-NT and LDH were found to be noticeably elevated in cancer possessing group II animals. On VA (Group III) treatment, the levels of these enzymes were considerably retained to near normal level while compared to group II animals.
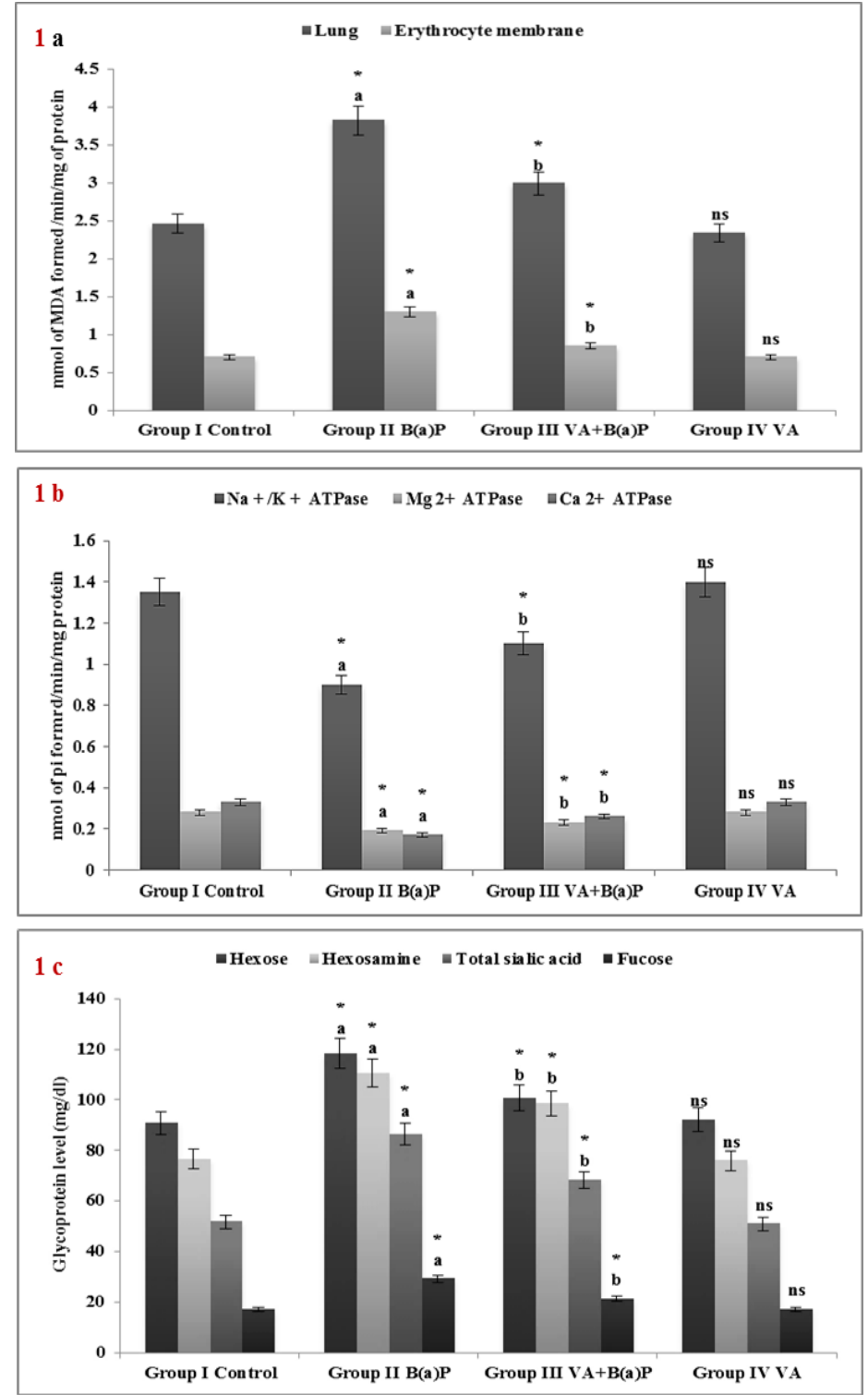

Fig. 1a: Levels of malondialdehyde (MDA) in lung and erythrocyte membrane, (fig. 1b) Levels of glycoconjugates, and (fig. 1c) Erythrocyte membrane ATPases activity in control and experimental animals, Results are expressed as mean $\pm S$. $D$ for six animals in each group. Results are given as statistically significant at ${ }^{*} \mathbf{p}<0.05$; as compared with Group I; b as compared with Group II; ${ }^{\mathrm{n}}$ : non-significant as compared to control. Units were expressed as mmol of $\mathrm{MDA}$ formed $/ \mathrm{min} / \mathrm{mg}$ of protein. $\mathrm{Mg} / \mathrm{ml}$. $\mathrm{nmol}$ of $\mathrm{pi}$ formed $/ \mathrm{min} / \mathrm{mg} \mathrm{protein}$ 


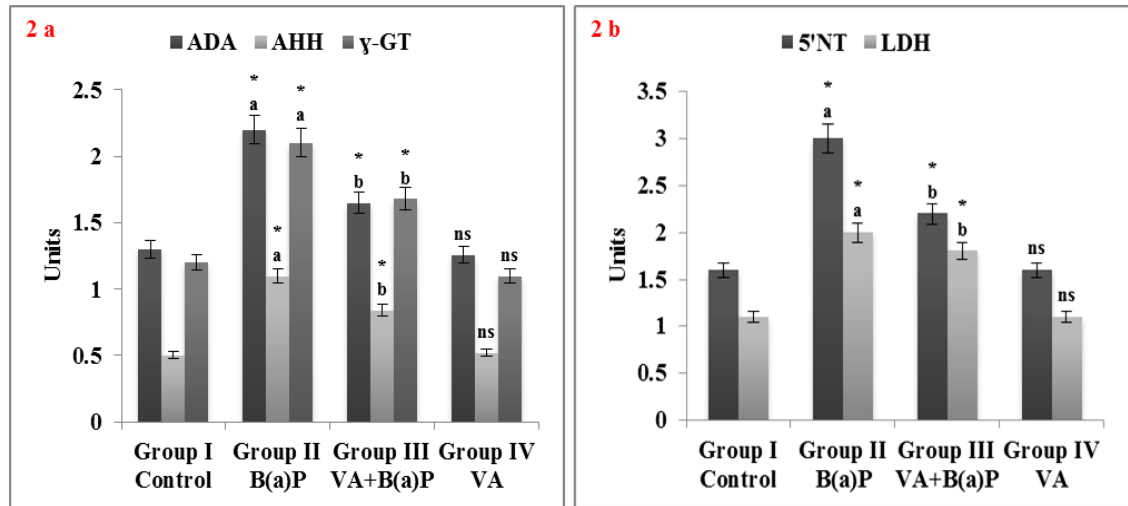

Fig. 2(a) and (b): Levels of serum marker enzymes in the control in the control and experimental group of animals, Results are expressed as mean $\pm S$. D for six animals in each group. Results are given as statistically significant at ${ }^{*}$ p $<0.05$; $^{\text {a }}$ as compared with Group $\mathrm{I}$; ${ }^{b}$ as compared with Group II; ns: non-significant as compared to control. Units: ADA-micro-moles of $\mathrm{NH}_{3}$ liberated/mg protein/hr.; AHHmicromoles of fluorescent phenolic metabolites formed/min/mg protein; $\gamma$-GT-nano-moles of p-nitroaniline formed/min/mg/protein; 5'-NT-nanomoles of Pi liberated/min/mg protein; LDH-micro-moles of pyruvate liberated/min/mg protein

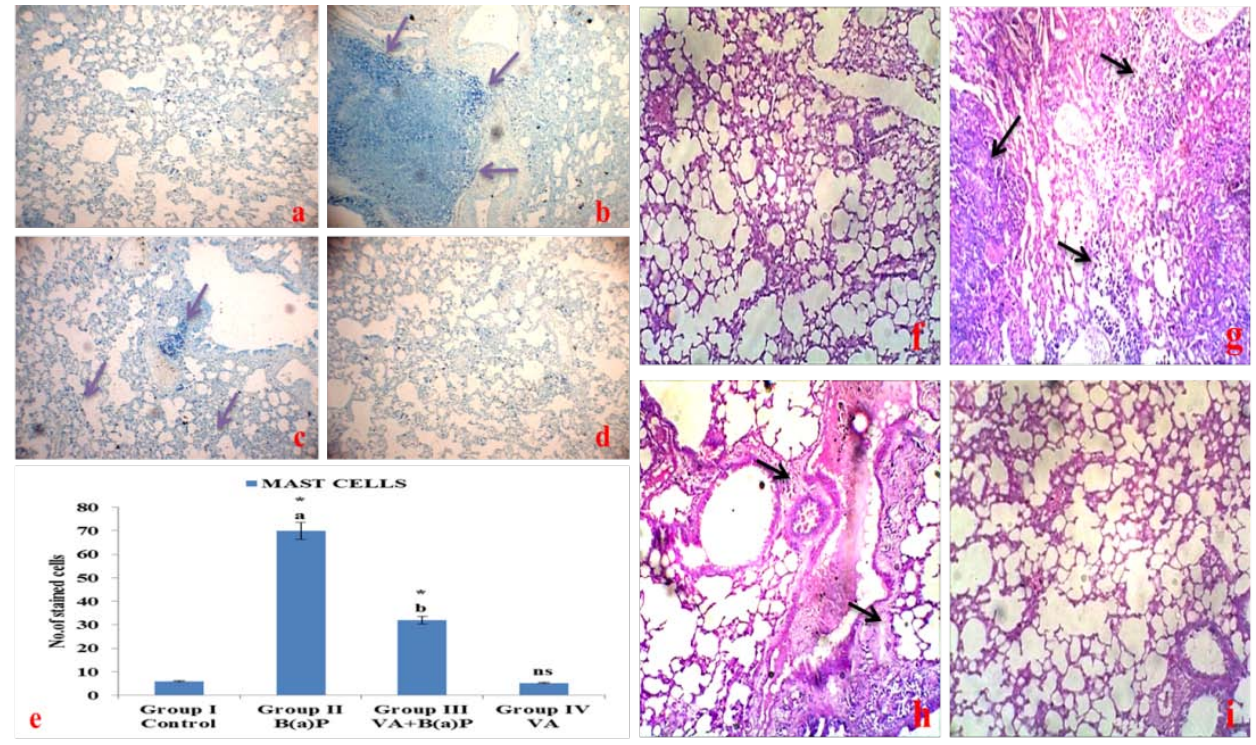

Fig. 3: Histochemical analysis of mast cells by toluidine blue staining and PAS staining in the lung of control and experimental animals (10X), fig. 3 (a) shows the section from control mice lung exhibits normal architecture with minimal mast cells. (b) Section from B(a)P induced mice lung showing an abnormally increased number of mast cell density (c) section from VA treated mice lung showing a reduced number of mast cell density and infiltration. (d) Section from drug control mice lung showing normal architecture as similar to that of normal control lung. Violet color arrows indicate positively stained mast cells. (e) Represents the average bar graph of the total number of mast cells in ten different fields/slides in control and experimental groups. The data expressed as mean \pm SD for six mice in each group. Statistically significant at ${ }^{*} \mathbf{p}<0.05$; as compared with Group I; ${ }^{b}$ as compared with Group II; ${ }^{\text {n: }}$ non-significant as compared to control. Fig. 3 (f) Control group shows normal glycoconjugate expression. (g) B(a)P induced lung cancer-bearing mice lung section (Black arrow) indicates overexpression of glycoconjugates. (h) Decreased expression of glycoconjugates in VA+B(a)P treated animals. (i) The Drug control group shows normal glycoconjugates expression as compared to the control group

\section{VA treatment reduced the mast cell infiltration}

Fig. 3 (a to d) shows the toluidine blue staining of control and experimental animals. Tumor possessing animals of group II showed the increased number of mast cells while compared to control animals. Whereas, VA treated animals revealed a substantial decrease in the number of mast cells while compared to cancer possessing animals. VA alone treated animals did not show any significant change when compared to control animals.

\section{VA reduces the levels of inflammatory cytokines}

Fig. 4 a, b and c depict the levels of TNF- $\alpha$ and IL- $1 \beta$ was markedly increased tumor possessing animals when compared to control animals. Whereas VA treated animals, revealed significantly reduced the protein expression of TNF- $\alpha$ and IL- $1 \beta$ when compared to lung cancer possessing animals.

Effect of VA administration on the activity of lung and erythrocyte ATPases in the control and experimental animals

Table 1, fig. 1b respectively shown the lung and erythrocyte ATPases, such as $\mathrm{Na}+\mathrm{K}+\mathrm{ATPase}, \mathrm{Mg} 2+\mathrm{ATPase}$, as well as $\mathrm{Ca} 2+\mathrm{ATPase}$ of control and experimental animals. Noticeable significant decrease in the levels of $\mathrm{Na}+\mathrm{K}+$ ATPase, Mg2+ATPase, and $\mathrm{Ca} 2+\mathrm{ATPase}$ was perceived in group II cancer possessing animals while compared to group I animals. Treatment of VA with $\mathrm{B}(\mathrm{a}) \mathrm{P}$ mice normalized the levels of lung and erythrocyte ATPases in group III animals. However, there were no significant changes in group IV animals while compared to control animals. 


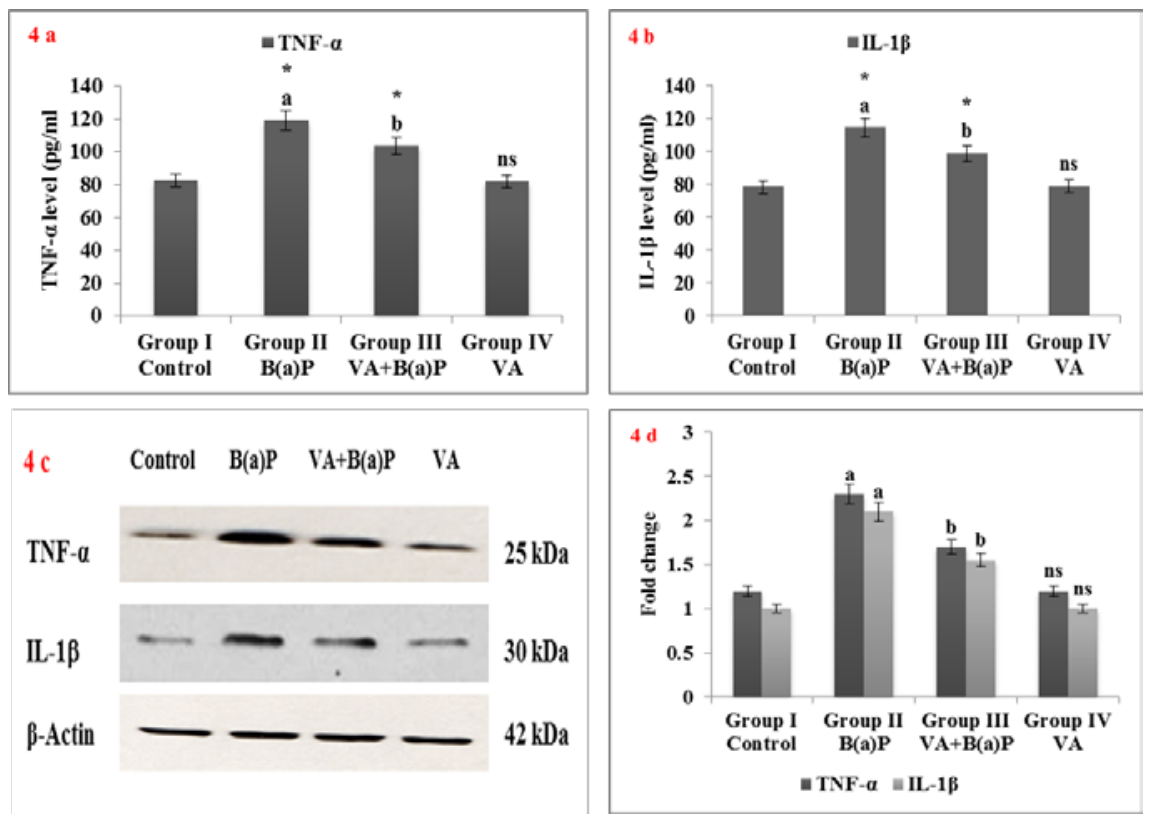

Fig. 4a and b: Effect of VA on TNF- $\alpha$ and IL-1 $\beta$ ELISA and fig. (4c) Immunoblot expression levels in experimental groups of animals, results are expressed as mean $\pm S$. D for six animals in each group. Results are given as statistically significant at ${ }^{*} \mathbf{p}<0.05$; $^{\text {a }}$ as compared with Group I; b as compared with Group II; ns: non-significant as compared to control. Fig. (4d) Quantitative data stating the equivalent protein levels were assessed using densitometry and is uttered as "fold change" as compared with control. Units were expressed as pg/ml

Table 1: Effect of VA administration on the activity of ATPases of lung tissue in the control and experimental groups

\begin{tabular}{|c|c|c|c|c|}
\hline Particulars & Group Icontrol & Group IIB(a)P & Group IIIVA+B(a)P & Group IVVA \\
\hline $\mathrm{Na}+/ \mathrm{K}+\mathrm{ATPase}$ & $6.22 \pm 0.26$ & $3.33 \pm 0.32^{* a}$ & $4.53 \pm 0.39^{* b}$ & $6.05 \pm 0.23^{\mathrm{ns}}$ \\
\hline $\mathrm{Mg}^{2+}$ ATPase & $10.98 \pm 0.4$ & $6.76 \pm 0.49^{* a}$ & $7.83 \pm 0.44^{* b}$ & $10.87 \pm 0.41^{\mathrm{ns}}$ \\
\hline $\mathrm{Ca}^{2+}$ ATPase & $9.62 \pm 0.31$ & $4.86 \pm 0.44^{* a}$ & $6.51 \pm 0.59^{* b}$ & $9.46 \pm 0.35^{\mathrm{ns}}$ \\
\hline
\end{tabular}

Results are expressed as mean \pm SD for six animals in each group. Results are given as statistically significant at * $<<0.05$; ${ }^{a}$ as compared with Group I; b as compared with Group II; ns: non-significant as compared to control. Units: $\mathrm{Na}^{+} / \mathrm{K}+\mathrm{ATPase}, \mathrm{Mg}{ }^{2+} \mathrm{ATPase}$ and Ca ${ }^{2+} \mathrm{ATPase}$ are expressed micromole $(\mu \mathrm{mol})$ of inorganic phosphate formed/min (mg/protein).

\section{Effect of VA administration on cell surface glycoconjugates abnormalities}

Fig. 1c, table 2 shows the levels of glycoconjugates (Protein-bound hexose, hexosamine, total sialic acid, then fucose) in the serum and lung tissues respectively. The levels of glycoconjugates in the serum and lung tissue significantly increased in administered with $\mathrm{B}(\mathrm{a}) \mathrm{P}$ animals while compared to control animals. Oral administration of $\mathrm{VA}+\mathrm{B}(\mathrm{a}) \mathrm{P}$ treated mice brought back the levels of the glycoconjugates to a nearer normal level. No significant difference was noticed in the levels of serum and lung glycoconjugates in VA alone group animals while compared with control animals. Fig. 3 (f to i) shows the PAS staining analysis also confirms the VA treatment during $\mathrm{B}(\mathrm{a}) \mathrm{P}$ administration.

Table 2: Effect of VA on glycoproteins like hexose, hexosamine, total sialic acid and fucose of lung tissue in the control and experimental animals

\begin{tabular}{llll}
\hline Particulars & Group Icontrol & Group IIB(a)P & Group IIIVA+B(a)P \\
\hline Hexose & $85.41 \pm 3.45$ & $109.65 \pm 9.27^{* a}$ & $97.32 \pm 7.08^{* b}$ \\
Hexosamine & $38.6 \pm 1.98$ & $67.2 \pm 6.91^{* a}$ & $84.61 \pm 5.22^{* b}$ \\
Total sialic acid & $15.72 \pm 1.08$ & $28.56 \pm 3.78^{* a}$ & $22.45 \pm 2.07^{* b}$ \\
Fucose & $13.3 \pm 1.21$ & $21.26 \pm 2.78^{* a}$ & $18.5 \pm 2.16^{* b}$ \\
\hline
\end{tabular}

Results are expressed as mean \pm SD for six animals in each group. Results are given as statistically significant at *p<0.05; a as compared with Group I; b as compared with Group II; ns: non-significant as compared to control. Units: hexose, hexosamine, total sialic acid, and fucose units are expressed $\mathrm{mg} / \mathrm{g}$ tissue protein.

\section{DISCUSSION}

During malignancy, the cell membrane plays a crucial role in the control of cell adhesiveness, cell death, as well as cell proliferation. Lipid peroxidation generally takes place fewer in normal physiological circumstances. The $\mathrm{B}(\mathrm{a}) \mathrm{P}$ is a very effective carcinogen with an ability to induce enormous amounts of free radicals generation, which in turn reacts with lipids causing LPO. In nature, there is a dynamic balance the number of free radicals generated in the body and antioxidant defense systems that reduce or scavenging them and protect the body against their adverse effects [36]. In the existing study, it is evident that an increased level of LPO was established in cancer possessing animals. However, the administration of VA decreased the LPO, which may be due to the free radical scavenging movement $[19,37]$.

ADA is an essential enzyme in purine metabolism as it catalyzes the translation reaction of adenosine to inosine [38]. AHH metabolizes some of the polycyclic hydrocarbons to phenols, dihydrodiols, quinines, and epoxides [22]. High levels of AHH were established in 
pulmonary in the serum and tissues of animals exposed to $\mathrm{B}(\mathrm{a}) \mathrm{P}$ [39]. GGT activity assists as a specific marker of the prediction of the carcinogenic process [40]. 5'-NT are enzymes that hydrolyze nucleotides with a phosphate group on carbon atom 5 of ribose. Increased activities of $5^{\prime}$-NT in tumorous animals appear to have originated from the proliferating tumor cells $[41,42]$. LDH is a fairly sensitive marker for solid neoplasms, also raised activity of the enzyme was designated in the serum of patients with lung cancer [43]. In the existing study, there was a substantial elevation in the levels of these enzymes in cancer possessing animals. VA treatment bought down the levels of these marker enzymes close to normal level shows that VA possesses defensive agents against carcinogenesis.

The inflammatory microenvironment of cancerous tissue is distinguished by the occurrence of host leukocytes both in the supportive stroma and between tumor cells, with macrophages, dendritic cells, T cells, and MCs [44]. Mast cells can secrete numerous proangiogenic factors, which can start the tumor angiogenesis switch and they have been shown to store in tissues undergoing angiogenesis through tumor progression [45]. The increased mast cells were related to reduce survival rates in patients through pulmonary adenocarcinoma [46]. VA supplementation animals exhibited significantly diminished in the mast cell density proves its chemopreventive nature.

Acute inflammation generated by exogenous administration of TNF$\alpha$ and IL-1 $\beta$ has been known under certain malignancy and metastasis [47]. TNF- $\alpha$ is predominately activated by macrophages and induces the variability of cellular response including apoptosis [48]. TNF- $\alpha$ has several possessions including lysis, hemorrhagic necrosis of tumor cells, and tissue destruction through adhesive molecules [49], which may stimulate the growth of fibroblasts and certain tumor cells [50]. IL-1 $\beta$ is a significant pro-inflammatory cytokine connected with chronic inflammation and is radically elevated in the levels of adenocarcinoma patient's serum [51,52].

The membrane protection is in need during the treatment of adverse conditions of the disease progression [53]. The membrane-bound enzymes such as $\mathrm{Na}^{+} / \mathrm{K}^{+} \mathrm{ATPases}, \mathrm{Mg}^{2+} \mathrm{ATPase}$, and $\mathrm{Ca}^{2+} \mathrm{ATPase}$ are liable for the transport of sodium/potassium, magnesium and calcium ions transversely on the cell membranes at the outflow of ATP by way of hydrolysis. $\mathrm{Na}^{+} / \mathrm{K}^{+} \mathrm{ATPase}$ movement is liable for a large part of the energy spending which constituents the essential metabolic enzyme activity and the changes in the membrane dynamic lead to pathological conditions $[4,5,54] . \mathrm{Ca}^{2+} \mathrm{ATPase}$ is a reflection of energy-dependent calcium transport across the cell membrane less deformable. $\mathrm{Mg}^{2+} \mathrm{ATPase}$, along with the other ATPase is also involved in energy-requiring processes in the cell. The protective effect of VA in this system could be either due to scavenging peroxides before attacking the membrane and or due to blocking the oxidation of membrane lipids.

Glycoproteins exert a significant part in contributing to the surface properties, tumorigenesis, and as mediators of immunological specificity. Malignant transformation is frequently associated with molecular variations such as glycoproteins and glycolipids. Increased levels of tissue and serum glycoprotein's hexose, hexosamine, sialic acid, and fucose during malignancy reflect moreover a local or systemic tissue response of the tumor [55]. Evidence from animal experimentation recommends that the presence of malignant tumors invoke the rise in the synthesis of glycoproteins, which subsequently enter into the circulation [56, 57]. These results were also agreed with our present examination from which we noticed an increased level of tissue glycoconjugates in lung cancer-induced animals. VA treatment considerably reduces the level of these glycoproteins to a near-normal state. These decreases in the levels of glycoprotein components signify that the VA can restrain malignancy by modulating cellular transformation to protect the cell wall abnormalities.

\section{CONCLUSION}

Our present investigation indicates that VA supplementation improved the levels of the inflammatory cytokines TNF- $\alpha$, IL- $1 \beta$ protein expression, disruptions in lipid peroxidation and membranebound enzyme activity, as well as glycoprotein levels during B(a)P induced lung cancer, thus confirms its chemopreventive effect. From all the above results, we conclude that the VA has a potential antiinflammatory, chemotherapeutic agent against $\mathrm{B}(\mathrm{a}) \mathrm{P}$ induced lung carcinogenesis in Swiss albino mice.

\section{ACKNOWLEDGMENT}

The author Mr. Sathesh Kanna V wishes to express thanks to Dr. Ramesh, Professor, Central Instrumentation lab, TANUVAS, Chennai, for his assistance in histopathological studies and also genuinely acknowledges Mrs. Saranya PM for her honorable support and encouragement.

\section{FUNDING}

Nil

\section{AUTHORS CONTRIBUTIONS}

All the authors have contributed equally.

\section{CONFLICT OF INTERESTS}

The authors wish to approve that there are no identified conflicts of interest.

\section{REFERENCES}

1. Khuri FR, Herbst RS, Fosella FV. Emerging therapies in nonsmall cell lung cancer. Ann Oncol 2001;12:739-44.

2. Winterhalder RC, Hirsch FR, Kotantoulas GK, Franklin WA, Bunn PA Jr. Chemoprevention of lung cancer-from biology to clinical reality. Ann Oncol 2004;15:185.

3. Ruano Ravina A, Figueiras A, Montes Martinez A, Barros Dios JM. Dose-response relationship between tobacco and lung cancer: new findings. Eur J Cancer Prev 2003;12:257.

4. Chandrasekar N, Subramanian R, Selvakumar A, John B, Thiruvengadam D. Baicalein improves antioxidant status and membrane-bound enzymes during oxidative stress in benzo(a)pyrene-induced lung carcinogenesis in mice. Biomed Preventive Nutr 2012;2:138-44.

5. Anandakumar P, Jagan S, Kamaraj S, Ramakrishnan G, Titto AA, Devaki T. Beneficial influence of capsaicin on lipid peroxidation, membrane-bound enzymes and glycoprotein profile during experimental lung carcinogenesis. J Pharm Pharmacol 2008;60:803-8.

6. Edward SK, Faldo RK. Chemoprevention of lung cancer. Curr Oncol 2002;4:341-6.

7. Ramakrishnan G, Titto AA, Jagan S, Vinodhkumar R, Devaki T. Effect of silymarin on N-nitrosodiethylamine induced hepatocarcinogenesis in rats. Exp Oncol 2007;29:39-44.

8. Sinha AK, Sharma UK, Sharma N. A comprehensive review on vanilla flavour: extraction, isolation and quantification of vanillin and other constituents. Int J Food Sci Nutr 2008;59:299-326.

9. Charrouf Z, Guillaume D. Phenols and polyphenols from argania spinosa. Am J Food Technol 2007;2:679.

10. Prince PSM, Rajkumar S, Dhanasekar K. Protective effect of vanillic acid on electrocardiogram, lipid peroxidation, antioxidants, proinflammatory markers and histopathology in isopretanol induced cardiotoxic rats. Eur J Pharmacol 2011;668:233-40.

11. Vetrano AM, Heck DE, Mariano TM, Mishin V, Laksin DL, Laskin JD. Characterization of the oxidase activity in mammalian catalase. J Biol Chem 2011;280:35372-81.

12. Guler EM, Nilufer C, Ozgur V, Dilek Y, Deniz B, Rahmi B. Genotoxic and Anti-genotoxic effects of vanillic acid against mitomycin C-induced genomic damage in human lymphocytes in vitro. Asian Pacific J Cancer Prev 2012;13:4993-8.

13. Vinoth A, Kowsalya R. Assessment of lipid peroxidation and antioxidant status in vanillic acid-treated 7, 12-dimethylbenz (a) anthracene-induced hamster buccal pouch carcinogenesis. J Can Res Ther 2018;14:1285-90.

14. Huang SM, Hsu CL, Chuang HC, Shih PH, Wu CH, Yen GC. Inhibitory effect of vanillic acid on methylglyoxal-mediated glycation in apoptotic neuro-2A cells. Neurotoxicology 2008;29:1016-22.

15. Tsuda H, Uehara N, Iwahori $Y$, Asamoo M, Ligo M, Nagao M, et al. Chemopreventive effects of beta-carotene, alpha-tocopherol 
and five naturally occurring antioxidants on initiation of hepatocarcinogenesis by 2-amino-3methylmidazo $(4,5)$ quinoline in the rat. Japanese J Cancer Res 1994;85:1214-9.

16. Itoh A, Isoda K, Kondoh M, Kawase M, Kobayashi M, Tamesada $\mathrm{M}$, et al. Hepatoprotective effect of syringic acid and vanillic acid on concanavalin a-induced liver injury. Bio-Pharm Bull 2009;32:1215-9.

17. Chiang LC, Ng LT, Chiang W, Chang MY, Lin CC. Immunomodulatory activities of flavonoids, monoterpenoids, triterpenoids, iridoid glycosides and phenolic compounds of plantago species. Planta Med 2011;69:600-4.

18. Jingli G, Shengxue Z, Shihai Y. Vanillic acid suppresses HIF-1 $\alpha$ expression via inhibition of mTOR/p70S6K/4E-BP1 and Raf/MEK/ERK pathways in human colon cancer HCT116 cells. Int J Mol Sci 2019;20:465.

19. kanna VS, Jagan S, Murugan M, Gopalakrishnan B, Devaki T. Protective effect of vanillic acid against benzo(a)pyreneinduced lung cancer in swiss albino mice. J Biochem Mol Toxicol 2019;33:e22382.

20. Bradford MM. A rapid and sensitive method for the quantitation of microgram quantities of protein utilizing the principle of protein-dye binding. Anal Biochem 1976;72:24854.

21. Galanti B, Giusti G. Direct colorimetric method for the determination of adenosine deaminase and 5'-AMP deaminase in the blood. Boll Soc Ital Biol Sper 1966;42:1316-20.

22. Mildred K, Richerd L, Joseph G, Alexander W, Conney A. Activation and inhibition of benzo(a)pyrene and aflatoxin B1 metabolism in human liver microsomes by naturally accruing flavonoids. Cancer Res 1981;41:67-2.

23. Orlowski M, Meister A. Isolation of $\gamma$-glutamyl transpeptidase from hog kiney. J Biol Chem 1965;240:338-47.

24. Hardonk MJ. 5'-nucleotidase. I. determinations of 5'nucleotidase isoenzymes in tissues of rat and mouse. Histochemie 1968;12:1-17.

25. King J. The transferases-alanine and aspartate transaminases. In: King J. Ed. Practical clinical enzymology. Van Nostrand Company Ltd., London; 1965c. p. 121-38.

26. Dodge JT, Hanahan DJ. The preparation and chemical characteristics of hemoglobin-free ghosts of human erythrocytes. Arch Biochem Biophys 1963;100:119-30.

27. Ohkawa H, Ohishi N, Yagi K. Assay for lipid peroxides in animal tissues by thiobarbituric acid reaction. Anal Biochem 1979;95:351-8.

28. Israel Y, Kalant H, Leblanc E, Bernstein JC, Salazar I. Changes in cation transport and $\left(\mathrm{Na}^{+} \mathrm{K}^{+}\right)$activated adenosine triphosphatase produced by chronic administration of ethanol. J Pharmacol Exp Ther 1970;174:330-6.

29. Hjerten $S$, Pan H. Purification and characterization of two forms of a low-affinity $\mathrm{Ca}^{2+}$ ATPase from erythrocyte membranes. Biochim Biophys Acta 1983;728:281-8.

30. Ohnishi T, Suzuki Y, Ozawa K. A comparative study of plasma membrane Mg2+ATPase activities in normal, regenerating and malignant cells. Biochim Biophys Acta 1982;684:67-74.

31. Niebes P, Berson I. Determination of enzymes and degradation products of mucopolysaccharide metabolism in the serum of healthy and varicose subjects. Bibliotheca Anatomica 1973;11:499-506.

32. Warren L. The thiobarbituric acid assay of sialic acids. J Biol Chem 1959;234:1971-5.

33. Ranieri G, Labriola A, Achille G, Florio G, Zito G, Zito AF, et al. Microvessel density, mast cell density and thymidine phosphorylase expression in oral squamous carcinoma. Int J Oncol 2002;21:1317-23.

34. Meloan SN, Valentine LS, Puchtler H. On the structure of carminic acid and carmine. Histochemie 1971;27:87-95.

35. Kamaraj S, Anandakumar P, Jagan S, Ramakrishnan G, Devaki T. Modulatory effect of hesperidin on benzo(a)pyrene-induced experimental lung carcinogenesis with reference to COX-2, MMP-and MMP-9. Eur J Pharmacol 2010;649:320-7.

36. Yogeeswaran G. Cell surface glycolipids and glycoproteins in malignant transformation. Adv Cancer Res 1983;38:289-350.
37. Sharmila S, Sathesh KV, Palanisamy K, Indumathi S, Manikandan $\mathrm{M}$, Nirmala $\mathrm{S}$, et al. Anti-cancer efficacy of umbelliferone against benzo(a)pyrene-induced lung carcinogenesis in swiss albino mice. Malaya J Biosci 2018;5:79-89.

38. Kocic G, Stanojevic V, Nagorm A, Brankovic N, Pavlovic D, Jevtovic T. Diagnostic importance of adenosine deaminase activity for progression and invasion of human colon tumors. Facta Universities 2003;10:76-8.

39. Amir M, Tiejuan M, Yang X, Rodney EK, Jiang-Fan C, Michael RB. Genetic removal of the $\mathrm{A} 2 \mathrm{~A}$ adenosine receptor enhances pulmonary inflammation, mucin production, and angiogenesis in adenosine deaminase-deficient mice. Am J Physiol Lung Cell Mol Physiol 2007;293:L753-L761.

40. Ngo EO, Nutter LM. Status of glutathione and glutathionemetabolizing enzymes in menadione-resistant human cancer cells. Biochem Pharmacol 1994;47:421-4.

41. Erdemli HK, Adam B, Bavbek N. Pyrmidine 5'nucleotidase I and II activities in acute leukaemias. Acta Medica (Hradec Kralove) 2004;47:129-31.

42. Dao TL, Ip C, Patel J. Serum sialyltransferase and 5'nucleotidase as reliable biomarkers in women with breast cancer. J Natl Cancer Ins 1980;65:529-34.

43. Anbarasi K, Sabitha KE, Devi CSS. Lactate dehydrogenase isoenzyme patterns upon chronic exposure to cigarette smoke: protective effect of bacoside A. Environ Toxicol Pharmacol 2005;20:345-50.

44. Coussens LM, Werb Z. Inflammation and cancer. Nature 2002;420:860-7.

45. Heissig B, Rafii S, Akiyama H, Ohki Y, Sato Y, Rafael T, et al. Low-dose irradiation promotes tissue revascularization through VEGF release from mast cells and MMP-9 mediated progenitor cell mobilization. J Exp Med 2005;202:739-50.

46. Tomita M, Mattsuzaki Y, Onitsuka T. Effect of mast cells on tumor angiogenesis in lung cancer. Ann Thorac Surgeons 2000;69:1686-90.

47. Balkwill F, Mantovani A. Inflammation and cancer: back to virchow? Lancet 2001;357:539-45.

48. Ben Bauch A. Host microenvironment in breast cancer development: inflammatory cells, cytokines and chemokines in breast cancer progression: reciprocal tumor-microenvironment interactions. Breast Cancer Res 2003;5:31-6.

49. Lejune FJ, Ruegg C, Lienard D. Clinical applications of TNFalpha in cancer. Curr Opin Immunol 1998;10:573-80.

50. Noguchi M, Hiwatashi N, Liu Z, Toyoto T. Secretion imbalance between tumour necrosis factor and its inhibitor in inflammatory bowel disease. Gut 1998;43:203-9.

51. Bartel DP. MicroRNAs genomics, biogenesis, mechanism, and function. Cell 2004;116:281-97.

52. Cheng-cheng W, Jia-rui Y, Chen-fei W, Nan Y, Juan C, Dan L, et al. Anti-inflammatory effects of Phyllanthus emblica $\mathrm{L}$ on benzopyrene-induced precancerous lung lesion by regulating the IL-1 $\beta / \mathrm{miR}-101 /$ lin $28 \mathrm{~B}$ signaling pathway. Integrative Cancer Ther 2017;16:505-15.

53. Thirunavukkarasu C, Sakthisekaran D. Stabilization of membrane-bound enzyme profiles by sodium selenite in $\mathrm{N}$ nitrosoethylamine induced and phenobarbitol promoted hepatocarcinogenesis in rats. Biomed Pharmacother 2003a;57:117-23.

54. Thirunavukkarasu C, Sakthisekaran D. Influence of sodium selenite on glycoprotein contents in normal and $\mathrm{N}$ nitrosodiethylamine initiated and phenobarbitol promoted rat liver tumors. Pharmacol Res 2003b;48:167-73.

55. Selvendiran K, Prince Vijeya Singh J, Sakthisekaran D. In vivo effect of piperine on serum and tissue glycoproteins levels in benzo(a)pyrene-induced lung carcionogenesis in Swiss albino mice. Pulmonary Pharmacol Ther 2006;19:107-11.

56. Mariline G, Renata S, Carolina RP, Helena C, Felix C, Maria LB, et al. Cellular models and in vitro assays for the screening of modulators of P-gp, MRP1 and BCRP. Molecules 2017;22:600.

57. Madankumar A, Jayakumar S, Devaki T. Geraniol, a component of plant essential oils prevents experimental oral carcinogenesis by modulating glycoprotein abnormalities and membrane-bound Atpase's. Int J Pharm Pharm Sci 2013;5:416-21. 